
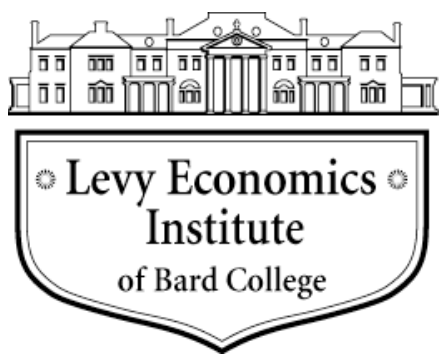

Working Paper No. 821

\title{
Outside Money: The Advantages of Owning the Magic Porridge Pot
}

by

\author{
L. Randall Wray* \\ Levy Economics Institute of Bard College
}

December 2014

*WrayR@umkc.edu

This paper was prepared for the project "Financing Innovation: An Application of a Keynes-SchumpeterMinsky Synthesis," funded in part by the Institute for New Economic Thinking, INET grant no. IN012-00036, administered through the Levy Economics Institute of Bard College. Co-principal investigators: Mariana Mazzucato (Science Policy Research Unit, University of Sussex) and L. Randall Wray (Levy Institute). The author thanks INET and the Levy Institute for support of this research.

The Levy Economics Institute Working Paper Collection presents research in progress by Levy Institute scholars and conference participants. The purpose of the series is to disseminate ideas to and elicit comments from academics and professionals.

Levy Economics Institute of Bard College, founded in 1986, is a nonprofit, nonpartisan, independently funded research organization devoted to public service. Through scholarship and economic research it generates viable, effective public policy responses to important economic problems that profoundly affect the quality of life in the United States and abroad.

Levy Economics Institute

P.O. Box 5000

Annandale-on-Hudson, NY 12504-5000

http://www.levyinstitute.org

Copyright (C) Levy Economics Institute 2014 All rights reserved

ISSN 1547-366X 


\begin{abstract}
Over the past two decades there has been a revival of Georg Friedrich Knapp's "state money" approach, also known as chartalism. The modern version has come to be called Modern Money Theory. Much of the recent research has delved into three main areas: mining previous work, applying the theory to analysis of current sovereign monetary operations, and exploring the policy space open to sovereign currency issuers. This paper focuses on "outside" money - the currency issued by the sovereign — and the advantages that accrue to nations that make full use of the policy space provided by outside money.
\end{abstract}

Keywords: Central Bank Independence; Chartalism; Fiat Money; Functional Finance; Innes; Keynes; Knapp; Modern Money Theory; Outside Money; Sovereign Currency; State Money

JEL Classifications: B1, B2, B3, B5, E5, E6 


\section{MINING PREVIOUS WORK}

There is a long intellectual history of thinking along the lines of what Knapp called the "state money" approach. In some respects, it was easier to see how sovereign currency works when the sovereign routinely and directly issued tally sticks or metal coins in its fiscal operations. Today, sovereign spending usually involves transactions among the treasury, the central bank, private banks, and bond markets. Still, it is surprising that economists had almost completely lost the state money tradition. Indeed, as the other chapters of this volume will make clear, economic theorizing had very little role for either inside or outside money to play. Money is always introduced into economic models through very simple ways - whether by "helicopter drops," "inheritance from the past," or "deposit multipliers." Once introduced, money is largely irrelevant - neutral in the long run and non-neutral in the short run only because of ad hoc assumptions. This casual and misleading treatment of money contributed to the two greatest economic disasters since the Great Depression: the Global Financial Crisis and the Euro Crisis. In both cases, economists "could not see it coming" because their understanding of money was deeply flawed. In the first instance, they misunderstood "inside" money and led the rush toward the financial excesses that inevitably led to the 2008 crash. In the second, they designed a currency system based on a fundamentally flawed understanding of sovereign currency, creating a union that would inevitably fail. The alternative framework offered by the state money tradition — broadly defined - provides the understanding that would have prevented both disasters.

There are far too many contributors and too many contributions to cover adequately in a short section, so I will focus on only a handful of the contributions that can give a flavor of what came before (See Wray 1990, 1998, and 2012 for other contributions). According to Knapp, money should be seen as a "token" of debt:

When we give up our coats in the cloak-room of a theatre, we receive a tin disc of a given size bearing a sign, perhaps a number. There is nothing more on it, but this ticket or mark has legal significance; it is a proof that I am entitled to demand the return of my coat. When we send letters, we affix a stamp or a ticket which proves that we have by payment of postage obtained the right to get the letter carried. The 'ticket' is then a good expression ... for a movable, shaped object bearing signs, to which legal ordinance gives a use independent of its material. Our means of payment, then, whether coins or warrants, possess the above-named qualities: they are pay-tokens, or tickets used as means of payment ... Perhaps the Latin word "Charta" can bear the sense of ticket or token, and we can form a new but intelligible adjective - "Chartal". Our means of 
payment have this token, or Chartal, form. Among civilized peoples in our day, payments can only be made with pay-tickets or Chartal pieces. (Knapp [1924] 1973, pp. $31-2)$

While the means of payment may be a definite material, it is not bound to any particular material, for it may be changed (ibid., pp. 8-25). "A proclamation is made that a piece of such and such a description shall be valid as so many units of value" (ibid. p. 30). "Validity by proclamation is not bound to any material. It can occur with the most precious or the basest metals ..." (ibid. p. 30). He recognized that these transitions require that the state announce a conversion rate (say, so many ounces of gold for so many ounces of silver). Hence, the debts are nominal—not actually "metallic" even if the token is made of metal:

It is, therefore, impossible to tell from the pieces themselves whether they are Chartal or not. This is at once evident in the case of warrants. As to coins, we must always refer to the Acts and Statutes, which alone can give information . . . if the pieces gain their validity through proclamation, they are Chartal (Ibid., pp. 34-5).

Money always signifies a Chartal means of payment. Every means of payment we call money. The definition of money is therefore a Chartal means of payment (ibid., pp. 34$8)$.

To borrow a phrase from A. Lerner that we'll revisit below, "money is a creature of the state":

If we have already declared in the beginning that money is a creation of law, this is not to be interpreted in the narrower sense that it is a creation of jurisprudence, but in the larger sense that it is a creation of the legislative activity of the State, a creation of legislative policy (Ibid., p. 40).

A.M. Innes wrote two amazing journal articles in 1913 and 1914 that more clearly laid out the nature of state money, and linked it to credit more generally. Innes believed that money evolves not from a pre-money market system but rather from the "penal system" based on the ancient practice of wergild (Ingham 2004; Wray 1998, 2004). Hence, he highlights the important role played by "authorities" in the origins and evolution of money. More specifically, the state (or any other authority able to impose an obligation) imposes a liability in the form of a generalized, social unit of account - a money — used for measuring the obligation. This does not require the preexistence of markets (as in the orthodox story that locates money's origins as a transactionscost-minimizing innovation that could replace barter), and, indeed, almost certainly predates them. Once the authorities can levy such obligations, they can name what fulfills this obligation by denominating those things that can be delivered, in other words, by pricing them. The state 
chooses the unit, names the thing accepted in payment of obligations to itself, and (eventually) issues the money thing it accepts. The material from which the money thing issued by the state is produced is not important (whether it is gold, base metal, paper, or, now, even digitized numbers at the central bank). No matter what it is made of, the state must announce its nominal value (that is to say, the value at which the money thing is accepted in meeting obligations to the state) and accept it in payments made to the state.

This led Innes to an alternative view of the nature of money. It is not some handy medium to mediate spot exchanges but instead is linked directly to the creation of credits and debts. Rather than selling in exchange for "some intermediate commodity called the "medium of exchange," a sale is really "the exchange of a commodity for a credit." Innes called this the "primitive law of commerce": "The constant creation of credits and debts, and their extinction by being cancelled against one another, forms the whole mechanism of commerce..." (Innes 1913, p. 393). Innes explains:

By buying we become debtors and by selling we become creditors, and being all both buyers and sellers we are all debtors and creditors. As debtor we can compel our creditor to cancel our obligation to him by handing to him his own acknowlegment [sic] of a debt to an equivalent amount which he, in his turn, has incurred (Innes 1913, p. 393).

The market, then, is not viewed as the place where goods are exchanged, but rather as a clearing house for debts and credits. Indeed, Innes rejected the typical view of the medieval village fairs, arguing that these were first developed to settle debts, with retail trade later developing as a sideline to the clearing house trade. On this view, debts and credits and clearing are the general phenomena; trade in goods and services is subsidiary—one of the ways in which one becomes a debtor or creditor (or clears debts). Innes viewed the creditor-debtor relation as the fundamental social relation lying behind money's veil. He also posed the "very nature of credit throughout the world," which is "the right of the holder of the credit (the creditor) to hand back to the issuer of the debt (the debtor) the latter's acknowledgment or obligation" (1914, p. 161). A debtor is "redeemed" by returning to his creditor the creditor's own debt in "redemption."

In this manner, Innes nicely links the State Theory of money to a Credit Theory of money. The state's own obligations (whether coin or paper currency, or longer-term obligations like bills and bonds) are held by creditors who have the right to "redemption" through delivery 
of those state IOUs in payment of taxes, fees, fines, and other obligations to the state. ${ }^{1}$ What, then, is special about government? The government's credit "usually ranks in any given city slightly higher than does the money of a banker outside the city, not at all because it represents gold, but merely because the financial operations of the government are so extensive that government money is required everywhere for the discharge of taxes or other obligations to the government" (Innes 1914, p. 154). The special characteristic of government money, then, is that it is "redeemable by the mechanism of taxation" (Innes 1914, p. 15): "[I]t is the tax which imparts to the obligation its 'value'.... A dollar of money is a dollar, not because of the material of which it is made, but because of the dollar of tax which is imposed to redeem it" (Innes 1914, p. 152).

Innes seems to have borrowed some of his ideas from much earlier work by Thomas Smith, ${ }^{2}$ who also rejected the commodity money view that he traced to Locke, Newton, and Ricardo. As Innes recognized, later, paper money retains value so long as it is accepted in redemption by its issuer:

Paper money has no intrinsic value; it is only an imputed one; and therefore, when issued, it is with a redeeming clause, that it shall be taken back, or otherwise withdrawn, at a future period. Unfortunately, most of the governments, that have issued paper money, have chosen to forget the redeeming clause, or else circumstances have intervened to prevent their putting it into execution; and the paper has been left in the hands of the public, without any possibility of its being withdrawn form circulation (Smith 1832, p. 49).

Smith also rejected the idea that gold backs paper money in the sense that it derives its value from gold; rather, it is a "representative" of the value of gold and all other things that can be valued (implicitly, in the money of account):

A bank note consequently is not a representative, as has been erroneously asserted, of any given quantity of gold or silver, any more than it is a representative at all times of the same quantity of tea, sugar, coffee, cotton, rum, butchers' meat, or any other commodity; but it is a representative and a very correct one, of a certain value of gold or silver, as well as of a certain value of all other commodities.

\footnotetext{
${ }^{1}$ Minsky(1970) provides an early and clear statement of the relation between money and obligations to pay: "For fiat money to be generally acceptable and valuable there must be a set of payments units must make for which this money will do. Taxes are such payments, thus, fiat money really should not be introduced without introducing a government with taxes and expenditures. Symmetrically, money as a liability of a fractional reserve bank acquires value in the market because there exist units, the debtors to the banks, which have payments to make for which this credit money will be acceptable. The acceptability and value of money depends upon the existence of payments denominated in that money: thus fiat money witho9ut a government that taxes and spends and credit money without debtors under constraint to meet payments commitments are quite meaningless concepts" (p. 23).

${ }^{2} \mathrm{http} / /$ /books.google.com/books/about/An_Essay_on_Currency_and_Banking.html?id=Nhw0AQAAMAAJ
} 
In an interesting analysis, Smith compares operations of the Bank of England with those of private banks, focusing on the business of discounting and issuing notes to facilitate government spending. Those notes then return to the issuers to repay debts to the banks.

[The Bank of England] issues its notes to merchants upon bills of exchange, or to government upon exchequer bills, or upon taxes to be levied, and in neither of these cases are the notes given out in the first instance. The bank only discounts to such parties, as hold what is called a discount account with it, to the credit of that account the net proceeds of the bills are first carried, and the party holding the account draws for the amount as it is wanted, and very frequently the notes are not taken at all, the draft being paid either to a private banker or to the bank itself, in lieu of obligations become due. The advances to government are conducted in the same manner, the amount to be advanced is placed to the credit of the treasury, or of the particular department for which it is destined, and the officers in that department draw for it, from time to time, as may be required. When the bills discounted, or the taxes on which the advances have been made, become due, then the notes which have been advanced are returned in payment. (p. 58)

This mode of issuing notes is not peculiar to the bank of England, it is followed by every respectable and well regulated bank...A bank discounts a bill of exchange or note of hand at sixty or ninety days, and gives its own notes, which are returned when the bill becomes due; but if, in the interim, these notes are presented, and gold demanded and received for them when the bill comes due, there will be no notes to retire it with.... [B]anks always hold securities for a larger amount than they have notes out. As they are not bound to take any thing except their own notes or specie; if they do not, or cannot, get the first, they must the last; and thus, not only the specie they have issued must revert to them, but, should they stop making fresh issues, a great deal more. (p. 59)

In other words, bank customers need the banks to issue the notes that debtors will use to make payments to the banks. Similarly, the Bank of England issues the notes that will be used to make payments on taxes. This emphasizes that the money must first be issued before it can be received - whether we are talking about bank money or central bank money advanced to government to spend.

In a series of points he concluded with his views on coins and paper money in contradistinction to what became orthodoxy: ${ }^{3}$

*That, ... coins were established as tokens, counters, or representatives of all articles; but to enable them to be so, they have to be issued by the government of the country and to have a fixed value attached to them...

\footnotetext{
${ }^{3}$ Original spelling has been retained; his points were originally numbered and I have removed the numbers as I have not repeated all the points he made
} 
*That, in all countries where coins circulate, the governments have retained the power of making and issuing them, of directing the quantity of metal to be put into them, and of fixing the value at which they are to pass within the country where they are issued, and which has invariably a reference to the point of comparison established in that country.

*That the precious metals, gold and silver, in bullion are not, never have been, and cannot possibly be the standards of value in any country, and have in fact no connexion whatever with it, until they are made into coins, and then they only pass as the representatives of the standard, not as the standard itself.

*That paper money is exactly similar to coins, only they have an intrinsic value which it has not, its value being altogether assumed, and consequently it circulates upon the faith that the parties issuing it will, at a future period, retire it from circulation.

*That the legitimate mode of withdrawing it, is by those parties receiving it back, in payment of the obligations for which it had original been issued.

*That coins labour under the inconvenience of being withdrawn from circulation and returned into bullion, whenever circumstances occur to raise the value of that bullion in the market.

*That no such thing can happen to paper money; it having no intrinsic value, as long as it passes at the rate it was issued to represent, it remains perfectly invariable.

*That, therefore, it is an erroneous and mistaken measure, to oblige the issuers of paper money to give coins for it. Paper money, being, for internal circulation, more commodious than coins, they will only be demand when required for exportation; and if they are received in exchange for the notes and exported, then, when the obligations, upon which the notes had been issued, become due, there will be no circulating medium in the field to retire them (pp. 62-63).

Commenting on the USA monetary mess of 1832, with private banks issuing notes that were easily counterfeited and with the government constrained to spending only minted coin, Smith recommended an interesting proposal. He argued that already, by 1832, paper dominated (unfortunately it was of questionable quality due to forgery and as well to bank refusal to redeem their notes):

The circulating medium of the United States has now become essentially a paper currency, and it will remain permanently so. There is no possibility of avoiding this; because, ...the daily transactions and exchanges are so numerous, and of such amounts, as to render the use of a metallic currency, especially of silver, at least extremely inconvenient if not perfectly impossible (p. 71).

He would let each US state establish a state bank that would issue notes against discounted commercial paper (something like the real bills doctrine that came later). These banks would 
have monopoly issue of small denomination, uniform, notes that would circulate freely across state borders, accepted in payment at par to any state's bank. Each state government would accept the notes in payment of taxes, and would finance spending with drafts on their account at their state bank. They would also borrow at low interest from the state banks (pp. 72-75). While Keynes's "General Theory” presented the theory of aggregate effective demand that is now identified as "Keynesian theory," his earlier "Treatise on Money" provided a more detailed treatment of his monetary theory. According to Keynes, the "money of account" is the "primary concept" of a theory of money; the money of account "comes into existence along with Debts, which are contracts for deferred payment, and Price-Lists, which are offers of contracts for sale or purchase" (Keynes, 1930, p. 3). In turn, "Money itself, namely that by delivery of which debt-contracts and price-contracts are discharged, and in the shape of which a store of General Purchasing Power is held, derives its character from its relationship to the Money-of-Account, since the debts and prices must first have been expressed in terms of the latter" (ibid.). He further clarifies the distinction between money and the money of account: "the money-ofaccount is the description or title and the money is the thing which answers to the description" (ibid., pp. 3-4).

Following Knapp, Keynes argued that the state determines what serves as the money of account as well as dictates what "thing" will be accepted as money.

The State, therefore, comes in first of all as the authority of law which enforces the payment of the thing which corresponds to the name or description in the contracts. But it comes in doubly when, in addition, it claims the right to determine and declare what thing corresponds to the name, and to vary its declaration from time to time- - when, that is to say, it claims the right to re-edit the dictionary. This right is claimed by all modern states and has been so claimed for some four thousand years at least (Keynes 1930, p. 4).

Privately issued debt — such as that issued by banks — might be accepted in settlement of transactions even if it is not declared by the government to be money; it can circulate "side by side" with "state money" (ibid., p. 6). However, the state might "use its chartalist prerogative to declare that the [bank] debt itself is an acceptable discharge of a liability" (ibid.). Bank money then becomes a "Representative Money" (ibid.).

At the cost of not conforming entirely with current usage, I propose to include as StateMoney not only money which is itself compulsory legal-tender but also money which the State or the central bank undertakes to accept in payments to itself or to exchange for compulsory legal-tender money" (ibid.). 
In a footnote to this passage, he goes on: 'Knapp accepts as 'Money'—rightly I think—anything which the State undertakes to accept at its pay-offices, whether or not it is declared legal-tender between citizens” (ibid. pp. 6-7). Therefore, like Knapp, Keynes's analysis goes beyond legal tender laws to identify state "acceptation" as the key to determining what will serve as money.

In summary, with the rise of the modern state, the money of account ("the description") is chosen by the state, which is free to choose that which will qualify as money ("the thing" that answers to the description). This goes beyond legal tender laws - which establish what can legally discharge contracts - to include that which the state accepts in payment at its "pay offices." The state is free to choose a system based on commodity money, fiat money or managed money. Even if it chooses a strict commodity system, the value of the money does not derive from the commodity accepted as money, "[f]or Chartalism begins when the State designates the objective standard which shall correspond to the money-of-account." (Keynes 1930, p. 11). "[M]oney is the measure of value, but to regard it as having value itself is a relic of the view that the value of money is regulated by the value of the substance of which it is made, and is like confusing a theatre ticket with the performance" (Keynes, 1983, p. 402). Once it is recognized that the state may "write the dictionary," it becomes obvious that the nominal value of a commodity (or managed) money cannot be derived from the value of the "objective standard"; it is then a small step to a "fiat money" with no "objective standard," for in all three cases, the state determines the nominal value of money. This is done when the state establishes what it will accept at public pay offices, as well as the nominal value of the thing accepted. Following the primary chartalist theme, Abba Lerner insisted that

[W] hatever may have been the history of gold, at the present time, in a normally wellworking economy, money is a creature of the state. Its general acceptability, which is its all-important attribute, stands or falls by its acceptability by the state (Lerner, 1947, p. 313).

Lerner's explanation on why the state's money is generally accepted is the same as that of Innes:

The modern state can make anything it chooses generally acceptable as money ... It is true that a simple declaration that such and such is money will not do, even if backed by the most convincing constitutional evidence of the state's absolute sovereignty. But if the state is willing to accept the proposed money in payment of taxes and other obligations to itself the trick is done. Everyone who has obligations to the state will be willing to accept the pieces of paper with which he can settle the obligations, and all 
other people will be willing to accept these pieces of paper because they know that the taxpayers, etc., will accept them in turn (Ibid.)

Like Innes and Keynes, Lerner argues that even if it has not always been the case, it surely is now true that the state writes the "description" of money when it denominates the tax liability in a money of account, and defines the "thing" that "answers to the description" when it decides what will be accepted at public pay offices. The "thing" which answers to the "description" is widely accepted not because of sovereignty alone, not because of legal tender laws, and not because it might have (or have had) gold backing, but because the state has the power to impose and enforce tax liabilities and because it has the right to choose "that which is necessary to pay taxes." As Lerner said, "Cigarette money and foreign money can come into wide use only when the normal money and the economy in general is in a state of chaos" (Lerner, 1947, p. 313). One might only add that when the state is in crisis and loses legitimacy, and in particular loses its power to impose and enforce tax liabilities, "normal money" will be in a "state of chaos," leading, for example, to the use of foreign currencies in private domestic transactions. In most cases, it is state money which is used, and state money is that which the state accepts in payment of taxes.

What Abba Lerner $(1943,1947)$ called his "money as a creature of the state" approach leads logically to his "functional finance" view of state budgeting. Because the state spends by emitting its own liability, it does not need tax revenue or the proceeds from borrowing in order to spend. He thus proposed two "principles" of functional finance. The first principle is that the state should increase taxes only if the public's income were too high (threatening inflation). His second principle is that the state should "borrow" (sell bonds) only if "it is desirable that the public should have less money and more government bonds" (Lerner 1943 p. 40). Lerner argued that government finance should be functional, that is, formulated with a view to accomplishing the government's goals, including full employment and low inflation. He opposed this to the notion of sound finance, which is the view that the government's budget should be set to "balance" tax revenues against spending. Few supporters of sound finance argue for a continuously balanced national government budget. They accept deficits in recession but typically argue that these should be largely offset by surpluses in expansions. Some allow for deficits so long as these are undertaken for "investment" type purposes (this would be analogous to a private firm's separation of its current account from its capital account, with its current account in balance but a deficit allowed on its capital account). 
Lerner insisted that all versions of sound finance should never be applied to the national government that issues its own currency. Government should never raise taxes to reduce its budget deficit, but rather should increase taxes only if inflation threatens. And, in line with the second principle, government should never sell bonds (what most economists call "borrowing") simply because it finds itself with a budget deficit. Rather, bonds should be sold only if there is downward pressure on interest rates, pushing them below the central bank's target rate.

To conclude this section, modern money is a state money: the state chooses the money of account, imposes taxes in that unit, and accepts payment in that unit. The state usually issues its own IOUs denominated in the same unit, and accepts its own IOUs in payment. Other entities typically also issue IOUs denominated in the state's money of account; issuers must accept their own IOUs in redemption. There is a hierarchy of monetary IOUs with the state's currency (including central bank reserves) at the top and used for clearing among financial institutions. State and bank IOUs must be issued first before they can be returned to their issuers in payment (redemption). Logically, the state must issue its currency through its spending or through lending before it can receive its currency in payment. The same is true of banks taken as a whole: they must lend their notes or deposits into existence before their creditors (note holders or depositors) can make payments to the banks. Unlike banks, however, the sovereign can ensure demand for its currency by imposing obligatory payments — such as taxes — that have to be paid in the sovereign's currency.

All of this was more transparent when sovereigns spent by "raising a tally" or by minting new coin to finance a war. It became a bit more obscure when they would offer exchequer bills for discounting by private banks, obtaining notes they would spend and collect in taxes. And after one bank was given monopoly power, to become the state's own bank- a central bankmatters apparently became opaque to many observers. The state no longer spent its IOUs, but rather ran its fiscal operations through its central bank, issuing bills, receiving credits to its account, spending central bank IOUs and receiving the same in tax payments. Much later, the private banks were brought into a triangle, with treasury spending leading to credits to private bank deposits, and taxes paid out of private bank accounts. All of this obscured sovereign finances, making it easier to suppose that the sovereign currency issuer operates like a household, receiving income (taxes) spending out of its receipts and "borrowing" if it was short. Problems with excessive note issue - due to wartime spending or issues to finance speculative excesses or issues of counterfeit notes-led to concerns and attempts to tie paper money to 
precious metal. The relatively brief experience with a gold standard changed thinking about sovereign finance and about "paper money" more generally. An alternative view evolved that maintained that it is necessary to tie the currency (and private bank notes) to metal. In the 1920s, the deposit multiplier was discovered, linking private deposit expansion to central bank reserves. In the 1950s the quantity theory was "restated" by M. Friedman, bringing the money stock to prominence but ironically consigning money to a bit part, determining nominal values. The understanding displayed above was lost.

\section{UNDERSTANDING SOVEREIGN MONETARY OPERATIONS}

The state money/chartalist approach has been revived in recent years by an approach called Modern Money Theory (MMT). (See Mosler 1995 for the earliest statement.) Following Innes, the state money approach is integrated with a Credit Money approach and also with various extensions such as the Circuit and Post Keynesian endogenous money approaches, W. Godley's sectoral balance approach (Godley and Lavoie 2007), H.P. Minsky's (1986) approach to financial instability, and the Marx-Veblen-Keynes monetary theory of production (M-C-M' in Marx; Theory of Business Enterprise in Veblen, and MTP in Keynes). In addition, more recent developments in monetary history (most prominently P. Grierson, 1977, and M. Hudson), in the sociology of money (G. Ingham 2004), anthropology (D. Graeber 2011), and central banking (C. Goodhart 1998) have all been synthesized in MMT. Among the most controversial of contributions of MMT has been to delve deeply into modern fiscal and monetary policy operations of sovereign governments. In an important sense, this work recovers the understanding developed by those examined above — by lifting the veil of complexity. Some of that complexity is due to old rules imposed on the belief they would constrain imprudent "printing" of money to finance spending.

We'll focus on the case of the United States, where the central bank (Fed) is supposed to be more powerful and independent than many central bankers. The US has three kinds of constraints that would seem to ensure that the US Treasury could not spend by "raising a tally" or by simply issuing coin. The Treasury must draw down its account at the Fed in order to spend; it cannot borrow funds directly from the Fed; and it is subject to a debt limit. Although Congress, alone, is granted the right to issue coin, in practice very little Treasury spending is financed through coinage. Almost all spending requires drawing on its account at the Fed, in 
which funds are accumulated through tax receipts and sales of Treasury debt to "markets." This is supposed to impose discipline on fiscal policy - to spend Treasury either needs to face taxpayers or bond vigilantes. If Treasury tries to spend excessively, taxpayers can revolt, and bond vigilantes can demand ever-higher interest rates. The third constraint is unusual for a sovereign government; it requires Congress to raise the debt ceiling in steps over time as outstanding Treasury debt rises. This occasionally leads to political bargaining, but only in recent years has it actually threatened to shut down government and generated some talk about possible defaults on federal government commitments.

However, as exposition by MMT scholars has made clear, the other two constraints are more apparent than real. It turns out that they can affect the sequencing of monetary and fiscal operations, but do not affect the outcome. Indeed, we typically find that fiscal operations include taxing, bond sales, and "money creation" in the form of crediting bank accounts. This is in contrast to the typical orthodox view of a "government budget constraint," according to which each of these is an alternative means of financing government spending - that is, that government chooses whether to "tax finance," "money finance," or "debt finance" its spending. The MMT argument is that all these operations are used but at different stages of the spending. The order, in turn, depends on institutional arrangements. Hence, we need to delve into the specific procedures followed.

Scott Fullwiler has shown that in the US case there are at least six transactions related to deficit operations. ${ }^{4}$ Unfortunately, there is no simple way to explain what follows without oversimplifying the procedures.

1. The Fed undertakes repurchase agreement operations with primary dealers (in which the Fed purchases Treasury securities from primary dealers with a promise to buy them back on a specific date) to ensure sufficient reserve balances are circulating for settlement of the Treasury's auction (which will debit reserve balances in bank accounts as the Treasury's account is credited) while also achieving the Fed's target rate. It is well known that settlement of Treasury auctions are "high payment flow days" that necessitate a larger quantity of reserve balances circulating than other days, and the Fed accommodates the demand. (Note that the point here is not that the Fed necessarily engages in operations that are equal to or greater than the auction, but that the operations ensure that sufficient balances circulate such that the auction settles without the effective federal funds rate for the day moving above the target rate. This requires that the balances already in circulation plus those added via operations are sufficient to settle the auction and enable banks in the aggregate to end the day with their desired positions at the target rate largely equal to actual positions.)

\footnotetext{
${ }^{4}$ This section follows Fullwiler et al. 2012.
} 
2. The Treasury's auction settles as Treasury securities are exchanged for reserve balances, so bank reserve accounts are debited to credit the Treasury's account, and dealer accounts at banks are debited. Treasury auctions can only settle via reserve balances using the Fed's Fedwire clearing and settlement system. The auction itself is an asset swap of reserve balances and thus does not affect the private sector's net wealth.

3. The Treasury adds balances credited to its account from the auction settlement to tax and loan accounts. This credits the reserve accounts of the banks holding the credited tax and loan accounts.

4. (Transactions 4 and 5 are interchangeable; that is, in practice, transaction 5 might occur before transaction 4.) The Fed's repurchase agreement is reversed, as the second leg of the repurchase agreement occurs in which a primary dealer purchases Treasury securities back from the Fed.

5. Prior to spending, the Treasury calls in balances from its tax and loan accounts at banks. This reverses the transactions in 3 .

6. The Treasury deficit spends by debiting its account at the Fed, resulting in a credit to bank reserve accounts at the Fed and the bank accounts of spending recipients. This increases the net financial wealth of the private sector.

What MMT stresses is that the end result is the same as it would be without the constraints discussed above. That is, if we eliminated the prohibition on selling treasury debt directly to the Fed or the requirement that the Treasury can spend only by drawing on its account at the Fed, the final balance sheet positions of the Treasury, the Fed, the nonbank public, and the private banks would be the same. Further, as mentioned above, we note that the Treasury spending involved all three operations - taxing creating "money" by crediting bank accounts, and issuing Treasury securities.

However, none of this should be too surprising. The central bank acts as the treasury's bank, ultimately receiving all payments to the Treasury and making all payments for the Treasury. Operations that involve only the Fed and Treasury have no impact on the nongovernment sectors - we can think of them as internal government accounting records. It would be simpler for the Treasury to issue bonds directly to the Fed, which would credit the Treasury's account which it would draw down as it made payments. Those payments would lead to credits by the Fed to bank reserves, and by banks to the accounts of the recipients of Treasury spending. If that led to excess reserves, then either the Fed or the Treasury would sell bonds to remove the excess reserves (if this were not done, the fed funds rate would fall-recall Lerner's Second Principle of Functional Finance). If we require the Treasury to sell bonds to private 
banks rather than to the Fed, then the Fed must ensure the banks have reserves to buy the bonds offered (by the Second Principle, the fed funds rate would rise if banks were short reserves).

Only reserve balances at the Fed can settle Treasury auctions via Fedwire and the only sources of reserve balances over time (that is, aside from various short-term effects from autonomous changes to the Fed's balance sheet) are loans from the Fed or the Fed's purchases of financial assets either outright or in repurchase agreements. The Fed normally purchases Treasury securities or requires Treasury securities as collateral for repurchase agreements (in the aftermath of the global crisis, the Fed has engaged in highly unusual purchases of a wider variety of assets, and has lent against various kinds of assets). Since existing Treasury securities were issued as a result of a previous government budget deficit, it is the case that the reserve balances required to purchase Treasury securities are the result of a previous government deficit or a loan (including repurchase agreements or purchases of private sector securities) from the Fed to the non-government sector. This is true even though the Treasury must have a positive balance in its account before it can spend, and even though the Fed is legally prohibited from providing the Treasury with overdrafts in its account due to the "self-imposed constraint." The Treasury's tax and loan account operations are for the purposes of aiding the Fed's ability to achieve the target rate, as is well established in the Fed's own literature and annual reports. And while the Treasury must issue bonds in order to replenish its own account when it runs a deficit, the interest rate on these bonds is largely determined by arbitrage against the Fed's target rate. This suggests that the self-imposed constraint is not really a constraint at all. Indeed, the government can leave excess reserves in the banking system so it has the choice of either spending with no bond sales while it pays the target rate on reserve balances or issuing debt as it spends, at essentially the central bank's target rate. For the US, the former is analogous to a scenario with no self-imposed constraint and with the Treasury obtaining overdrafts to its account at the Fed when it deficit spends, whereas the latter is obviously what occurs with no overdrafts allowed. In other words, prohibiting overdrafts leaves the Treasury issuing bonds that arbitrage against the Fed's target rate. There is no economically significant difference-if given the choice between an overdraft at the target rate or issuing debt at roughly the target rate, it is not economically significant for the Treasury's purposes if the former choice is then prohibited. (And while the Treasury may issue longer-term bonds that can be issued at significantly higher interest rates than the Fed's target rate, this is a "debt management" choice, not anything enforced by private debt markets.) Thus, treasury security interest rates are a matter of political 
economy rather than being set in a loanable funds market or subject to the whims of bond vigilantes.

When Treasury spending exceeds tax revenue, the private sector's net financial wealth is increased by the amount of the deficit. This outcome is irrelevant to the different sequencing of the Treasury's debt operations — whether bonds are sold before spending or after spending does not change the fact that deficits add net financial assets rather than "crowding out" private sector financial resources. Indeed, primary dealers finance their purchases of bonds at auction in the repo market, mostly using treasuries as collateral, while the newly issued bond will likely serve as collateral for further credit creation in financial markets. Far from "crowding out," bonds can actually enable further credit creation than would occur in their absence.

In summary, separating the Treasury and the Fed and adding the rule that the Treasury must finance its operations in the open market results in the six transactions described above for the Treasury's debt operations compared to the relatively simpler alternative of financing Treasury spending by issuing currency or by issuing debt to the central bank against notes used to finance spending. Nevertheless, the end result would be the same. Unfortunately, and most importantly, the added complexity is counter-productive because it leads to poor understanding among economists, poor modeling, and bad policy choices. Were economists and policy makers to understand that the "constraints" really are not operative, all three could be markedly improved. In the next section we show how our understanding of policymaking is changed.

\section{POLICY SPACE OPEN TO SOVEREIGN CURRENCY ISSUERS}

The conventional view that reasons from a government budget constraint (GBC) suggests that government's policy space is severely constrained. It essentially presumes government is a "user" of its currency, not an issuer. In that, it is like a household or a firm as it must obtain "income" (revenue from taxes, fees, fines) or "borrow" (issue treasury securities). While it is true that orthodoxy recognizes government can "print money" (the US Constitution, after all, gives to the Federal Government the monopoly over coin issue), it is believed that this is the final resort of the imprudent government - with inevitable references to hyperinflation of Weimar Germany or of the more recent experience of Zimbabwe. Indeed, the constraints discussed in the last section are supposed to make it much more difficult for government to follow that path. The supposed "independence" of central banks is an added barrier, with 
unelected officials protecting the value of the currency through their ability to veto money printing.

In fact, as argued above, the GBC misunderstands the government finance process, the analogy to currency users such as households is misplaced, and the constraints and central bank independence do not prevent "money printing." That is not to say that the conventional view has no impact, because by propagating misunderstanding, policymaking is influenced. In particular, the notion that sovereign government faces default risk and insolvency, or at least that it is subject to the whims of "bond vigilantes" is commonplace and induces policymakers to adopt principles of "sound finance" rather than "functional finance."

If we travel back in time to the days when sovereigns "raised a tally" or called in all the metal coins for recoining, the logic of "state finance" is clear. As the issuer of a nominally valued currency, the sovereign cannot run out of nominal money. Hazelwood sticks are abundant, but even if they were not, one only need to carve more notches, or carve bigger notches to indicate higher nominal values. While precious metal is limited, by recoining, the sovereign can declare higher nominal values for the new coins. As Innes and others insisted, the value of the sovereign's currency is determined by the value at which it is accepted at the state's pay houses. Further, the sovereign must spend the currency first, logically, before taxpayers can deliver it to those pay houses.

When we introduce banks, or a central bank, as intermediaries between the exchequer and the subjects/citizens of the sovereign state, things become a bit more complicated but the logic remains the same. The exchequer submits bills to the bank, which supplies notes or deposits to finance sovereign spending. The receipt of notes or deposits allows taxes to be paid with those notes or deposits, allowing the state to redeem the bills. The exchequer cannot run out of bills and the banks cannot run out of notes/deposits. The only complication that arises is that the banks might refuse the bills. That problem is resolved by creation of the court's banker - the central bank - and the rise of the modern sovereign state with political legitimacy. While we cannot completely rule out a "banker's strike" against modern democratic government, the likelihood is remote. In the US the Fed stands ready to lend reserves as necessary (in response to the Global Financial Crisis, the Fed originated nearly $\$ 30$ trillion in loans to banks and central banks) to stabilize financial markets-including dealer banks that make markets for US treasuries. Voluntary default by sovereign government is also possible, but 
again the risk is small (but not zero, as Russia demonstrated - and some Tea Party conservatives contemplated voluntary default in the US during the 2013 debate over raising the debt limit). What this means is that affordability is not the issue-sovereign government is not like a household or firm. It does, however, face three potential constraints: real resources, inflation, and exchange rates.

a. Real Resources: Government can only buy what is for sale in its own currency. In developed nations, all domestic resources available for purchase are typically for sale in domestic currency. Government must weigh the benefits of public use versus private use; that is both an economic issue and a political issue. Up to full employment, government can put resources to use without reducing private use. However, some argue that it is necessary to leave some resources idle as a buffer to prevent prices from rising.

b. Inflation: At full employment of resources, if government increases its utilization it must bid them away from other uses. Inflation is a likely result. However, even before full employment, increasing use will cause prices to rise in any sector where the demand elasticity of output is less than one. Note that opening the economy to imports can raise the elasticity of output, helping to reduce inflation pressures. Furthermore, such inflation is not necessarily bad, as it can encourage investment and innovations in those sectors.

c. Exchange rates: Rising government purchases might affect the exchange rate as domestic inflation rises (this is thought to cause depreciation) and as imports rise (also thought to depreciate a currency). To forestall such effects, government can try to peg or manage exchange rates. However, this can constrain policy space since foreign currency reserves will be needed. Pegging to a foreign currency (or, similarly, to gold) even introduces the problem of involuntary default: although the government can meet commitments in its own currency, it might not be able to provide foreign currency (or gold) on demand at the pegged rate.

Some argue that even if a sovereign government that issues its own nonconvertible currency (that is, one that is not pegged to foreign currency or gold) cannot be forced into involuntary default, it can be pushed into an "unsustainable" interest rate-debt spiral. Running deficits increases outstanding debt, which pushes up interest rates. To simplify a bit, if the interest rate on treasuries exceeds the economy's growth rate, the debt-to-GDP ratio explodes. 
Even if government can service its debt through central bank credits to accounts of bondholders, its deficit also explodes due to interest payments.

However, there are three responses to this fear. First, the interest rate is a policy variable. While central banks typically only target the overnight interbank lending rate, by keeping that low, they keep longer rates low on sovereign securities. Further, central banks can stand ready to buy longer maturities and thereby directly lower longer rates, too. Second, "debt management" is a policy variable, too. There is nothing in principle to keep the Treasury from issuing only short-term securities - even overnight securities. Extending Lerner's Second Principle of functional finance, we understand that the operational purpose of securities is to provide an interest-earning alternative to bank reserves (recall that reserves paid zero interest in the US until recently). If the central bank pays interest on reserves, that is functionally equivalent to issuing overnight treasury securities. Third, it isn't reasonable to assume with an exploding deficit ratio that GDP growth remains below the interest rate. Deficit spending by government (including interest service) increases nongovernment sector incomes and (most likely) spending. Even if the economy is operating at full employment, nominal GDP will grow faster (due to inflation). Some fear that nominal interest rates will rise to remain above nominal GDP growth (a Fisher Effect), but again that either presumes central banks cannot, or do not want to, restrain interest rates.

Before moving to the concluding section, let us return to the issue of central bank independence. There are a number of indices that claim to rank central banks according to degree of independence and some studies link that to inflation. These typically rank the US Fed (and the Bundesbank before unification, or the ECB after unification) as relatively independent. Even if we dismiss the claim that bond market vigilantes can push up sovereign interest rates by arguing that the central bank can control rates, there is the possibility that, say, the Fed would refuse to relieve pressure on the Federal government's finances. However, the claims for Fed independence are overstated. First, for the reasons discussed above, the Fed must coordinate with Treasury operations to ensure it can hit overnight rate targets. Second, the Fed is a "creature of Congress," created by public law that has been amended several times. This is recognized by the Fed, itself. In a clear analysis, the Fed's Bruce K. MacLaury put it this way:

What does "independence" mean? Is the Federal Reserve accountable? Is it responsive to changing national priorities? 
First, let's be clear on what independence does not mean.

It does not mean decisions and actions made without accountability. By law and by established procedures, the System is clearly accountable to congress-not only for its monetary policy actions, but also for its regulatory responsibilities and for services to banks and to the public.

Nor does independence mean that monetary policy actions should be free from public discussion and criticism - by members of congress, by professional economists in and out of government, by financial, business, and community leaders, and by informed citizens.

Nor does it mean that the Fed is independent of the government. Although closely interfaced with commercial banking, the Fed is clearly a public institution, functioning within a discipline of responsibility to the "public-interest." It has a degree of independence within the government - which is quite different from being independent of government.

Thus, the Federal Reserve System is more appropriately thought of as being "insulated" from, rather than independent of, political-government and banking - special interest pressures. Through their 14-year terms and staggered appointments, for example, members of the Board of Governors are insulated from being dependent on or beholden to the current administration or party in power. In this and in other ways, then, the monetary process is insulated — but not isolated - from these influences.

In a functional sense, the insulated structure enables monetary policy makers to look beyond short-term pressures and political expedients whenever the long-term goals of sustainable growth and stable prices may require "unpopular" policy actions. Monetary judgments must be able to weigh as objectively as possible the merit of short-term expedients against long-term consequences - in the on-going public interest.

....Ultimately the System is accountable to congress, not the executive branch, even though Reserve Board members and the chairman are president-appointed. The authority and delegated policy powers are subject to review by the congress not the president, the Treasury Department, nor by banks or other interests.

....The central bank is in constant contact with the Treasury Department which, among other things, is responsible for the management of the public debt and its various cash accounts.

Prior to the existence of the Federal Reserve System, the Treasury actually carried out many monetary functions. And even since, the Treasury has often been deeply involved in monetary functions, especially during the earlier years.

At the beginning of World War II, it appeared desirable that the Treasury be able to issue debt at relatively low interest cost and also on a basis that assured purchasers that securities would be marketable at near face value. Because of the urgency of this need, 
the policy was agreed to and continued after the war until 1951. During this period, the Treasury was, in effect, deciding the monetary policy of the country as it made its decisions as to how much debt needed to be funded. Because the central bank supported the market for government securities, it was forced to purchase amounts of securities necessary to maintain low interest rates and the par value of securities. Thus, as the Treasury issued additional debt, the central bank was forced to acquire part of that debt. This process resulted in direct addition to bank reserves.

Following the 1951 accord between the Treasury and the Federal Reserve System, the central bank was no longer required to support the securities market at any particular level. In effect, the accord established that the central bank would act independently and exercise its own judgment as to the most appropriate monetary policy. But it would also work closely with the Treasury and would be fully informed of and sympathetic to the Treasury's needs in managing and financing the public debt. In fact, in special circumstances the Federal Reserve would support financing if unusual conditions in the market caused an issue to be poorly accepted by private investors.

The Treasury and the central bank also work closely in the Treasury's management of its substantial cash payments and withdrawals of Treasury Tax and Loan account balances deposited in commercial banks, since these cash flows affect bank reserves. ${ }^{5}$

Frank N. Newman, ${ }^{6}$ former Deputy Secretary of the US Treasury, shed light on the way the Treasury views constraints on financing its deficits:

I recall from my time at the Treasury Department that the assumption was always that there was money in the fed account to start with. Nobody seemed to know where it came from originally or when; perhaps it was established in biblical times. But as a matter of practice, if the treasury wanted to disburse $\$ 20 \mathrm{bn}$ a given day, it started with at least that much in its fed account. Then later would issue new treasuries and rebuild its account at the fed. (I do not recall ever using an overdraft.)

In my view, this is still consistent with the MMT perspective that you mentioned, and in my own book the explanation starts the cycle with government spending, thus adding to the money supply, and then issuing treasuries for roughly equivalent amount, thus restoring the money supply and the Treasury's Fed account to the levels they were prior to that round of spending. Every cycle is: spend first, then issue treasuries to replenish the fed account. The fact that Treasury started the period with some legacy funds in its Fed account is not really relevant to understanding the current flow of funds in any year. [In practice, Treasury varies its issuance not only to match outlays, but also to deal with seasonal factors, and to avoid wide swings in new-issue sizes; so at one point of a year,

\footnotetext{
${ }^{5}$ Perspectives on Federal Reserve Independence - A Changing Structure for Changing Times Bruce K. MacLaury Published January 1, 1977 http://www.minneapolisfed.org/publications_papers/pub_display.cfm?id=690.

${ }^{6}$ Stephanie Kelton, "Former Dept. Secretary of the U.S. Treasury Says Critics of MMT are 'Reaching,"” New Economic Perspectives, October 30, 2013, http://neweconomicperspectives.org/2013/10/former-dept-secretary-u-streasury-says-critics-mmt-reaching.html.
} 
treasury might actually issue some extra securities because the next month was expected to have low tax revenues, or might not fully replenish recent spending because the next month was expected to have high tax revenues. That seasonal process doesn't really affect the overall flow of funds over a year. The substance of the cycle is still: spend then replenish. Debating that would seem highly philosophical, and would miss the practical aspects of the flows.]

In any case, the treasury can always raise money by issuing securities. The bond vigilantes really have it backwards. There is always more demand for treasuries than can be allocated from a limited supply of new issues in each auction; the winners in the auctions get to place their funds in the safest most liquid form of instrument there is for US dollars; the losers are stuck keeping some of their funds in banks, with bank risk. (I even try to avoid using the expression "borrow" when the treasury issues securities; the treasury is providing an opportunity for investors to move funds from risky banks to safe and liquid treasuries.)

\section{THE MAGIC PORRIDGE POT: CONCLUSIONS}

It is common to distinguish between "inside" (bank-created) and "outside" (governmentcreated) money. In general, that is a good thing. However, in orthodox treatments the main reason to do this is to relegate "outside" money to determination of inflation. Further, orthodoxy (and even most heterodoxy) attributes outside money creation to the central bank, while ignoring the role of the Treasury. In practice, in normal times (that is, previous to Quantitative Easing), central bank creation of High Powered Money (HPM) in its monetary operations is orders of magnitude smaller than creation of HPM through fiscal operations. Government budget deficits create HPM dollar-for-dollar, so a US budget deficit of $\$ 300$ billion creates the same amount of HPM, which is much larger than typical Fed net open market purchases or discount window borrowing. However, excessive HPM is removed through bond sales; again, most of these will be through the Treasury's new issue market rather than through Fed net open market sales. That seems to be the reason that economists ignore the fiscal impacts on "outside" money. And while it might be true that fiscal operations affect prices, it is highly misleading to link inflation to central bank creation of outside money. Central banks typically accommodate demand for HPM as part of their interest rate targeting. By contrast, fiscal policy can directly affect prices by bidding up prices in sectors that have an elasticity of production below one. However, there is no monetary magic involved: if fiscal policy affects prices, it is through spending, not money creation. And "inside" money creation can do that, too, by financing 
spending of households, firms, foreigners, and local government spending. The orthodox distinction between inside and outside money on that score is misplaced.

Many conventional analyses do recognize that outside money is used for clearing. The hierarchical arrangement means that state liabilities (treasury and central bank) are used for clearing purposes and also are held as a liquid assurance against uncertain outcomes. In terms of the analysis above, there is a pyramid of "moneys" with the state's HPM at the top. In a crisis, there is an attempt to liquidate nongovernment liabilities lower in the pyramid in favor of government liabilities higher in the pyramid. The central bank can stop a run by acting as lender of last resort. The treasury can help by insuring some of the liabilities of banks-generally, those that are essential to operation of the payments system.

Note that neither inside money nor outside money is a scarce resource. Banks lend their own IOUs; sovereign governments spend their own IOUs or lend them. Neither banks nor government can run out. If we think of an economy with only one bank that issues a nonconvertible note or deposit, it can always issue its own IOUs in lending and to pay interest. It cannot really be forced to default, although it can become insolvent in the sense that the value of its assets falls below its liabilities. But even an insolvent monopoly bank can always make all payments as they come due. Regulations and supervisory oversight are required to curtail operations and to shut down an insolvent bank. In a sense, the monopoly bank has a magic porridge pot.

If we add many banks that need to clear payments among one another, default becomes possible for an individual bank should other banks refuse to accept that bank's IOUs for clearing. With modern central banking and deposit insurance, that is not a likely outcome because government makes sure bank IOUs clear at par with one another and that depositors can always get currency if they prefer. Rules, regulation, and oversight are designed to ensure that individual banks perform good underwriting so that losses are small; that ensures that par clearing does not normally require the central bank or treasury to intervene. While banks could make bad loans and still make good on their own IOUs even while insolvent, the problem is that they face clearing drains and oversight. We can think of the finance provided by banks as potentially infinite, however the supply of good borrowers is finite and it is the job of the banker to find them. If they are not successful, the government supervisors will intervene and eventually will shut them down as net worth reaches a lower threshold. For that reason, private banks really do not have a magic porridge pot. 
The sovereign currency issuer ensures demand for the currency by imposing obligations - taxes, fees, and fines. In developed nations, the sovereign's money of account is used to denominate virtually all monetary liability and prices, and sovereign currencyincluding central bank reserves - is the ultimate clearing medium. As Newman says in the quote above, there is always excess demand for the sovereign's liabilities. Deficits allow the nongovernment sectors to accumulate safe and liquid claims on the sovereign government. However, in at least some developing nations that is not true - a foreign currency such as the US dollar can be preferred for clearing and the foreign money of account is even used for denominating some transactions. In those nations, the domestic government does not really have the magic porridge pot - it might be forced to obtain foreign currency even for domestic use. Its policy space is to that extent constrained. Nations that peg to a foreign currency (or to gold) cannot manufacture that "porridge."

And, hence, the problems with the EMU. But that is a topic for another day and another paper. 


\section{References}

Fullwiler, S.T, Kelton, S.A, and Wray, L.R. (2012) "Modern Money Theory: A Response to Critics," Political Economy Research Institute, Working Paper 279.

Godley, W. and Lavoie, M. (2007) Monetary Economics: An Integrated Approach to Credit, Money, Income, Production and Wealth, New York: Palgrave Macmillan.

Goodhart, C.A.E. (1998) "Two Concepts of Money: Implications for the Analysis of Optimal Currency Areas," European Journal of Political Economy, 14: pp. 407-432.

Graeber, D.R. (2011) “Debt: The First 5000 Years,” Brooklyn, N.Y.: Melville House.

Grierson, P. (1977) “The Origins of Money,” London: The Athlone Press.

Ingham, G. (2004) "The Nature of Money," Cambridge: Polity

Innes, A.M. (1913) "What is Money?," Banking Law Journal, May: pp. 377-408. Republished as "What is Money?"; in L. Randall Wray (ed) 2004, Credit and State Theories of Money, Cheltenham: Edward Elgar.

(1914) "The Credit Theory of Money," Banking Law Journal, January: pp. 151-168. Republished as "The Credit Theory of Money" in L. Randall Wray (ed) 2004, Credit and State Theories of Money, Cheltenham: Edward Elgar.

Keynes, J.M. ([1930] 1976) “A Treatise on Money, Volumes I and II,” New York: Harcourt, Brace \& Company.

(1964) “The General Theory,” New York: Harcourt-Brace-Jovanovich.

(1983) "The Collected Writings of John Maynard Keynes, Volume XI: Economic Articles and Correspondence, Academic," edited by Donald Moggridge, London and Basingstoke: Macmillan/Cambridge University Press.

Knapp, G.F. ([1924]1973) “The State Theory of Money,” Clifton, NY: Augustus M. Kelley.

Lerner, A. (1943) "Functional Finance and the Federal Debt," Social Research, vol. 10, pp. 3851.

(1947) "Money as a Creature of the State," American Economic Review, 37(2), May, pp. 312-17.

Minsky, H.P. (1970) “The Reconsideration of Keynesian Economics,” Working Paper, Washington University, St. Louis, available as Paper 475, Hyman P. Minsky Archive, Bard Digital Commons, http://digitalcommons.bard.edu/hm_archive/475. (1986), “Stabilizing an Unstable Economy,” New Haven, CT: Yale University Press. 
Mosler, W. (1995) “Soft Currency Economics, 3rd edn.,” West Palm Beach, FL (self published). Http:॥www.warrenmosler.com.

Wray, L.R. (1990) "Money and Credit in Capitalist Economies: The Endogenous Money Approach," Aldershot, UK and Brookfield, US: Edward Elgar. (ed., 2004) "Credit and State Theories of Money," Cheltenham, Edward Elgar. (1998) “Understanding Modern Money,” (Cheltenham, Edward Elgar). 2012 "Modern Money Theory: A Primer on Macroeconomics for Sovereign Monetary Systems," Palgrave. 